\title{
Comparison of Fibroblast and Osteoblast Response to Cultivation on Titanium Implants with Different Grain Sizes
}

\author{
Vaclav Babuska, ${ }^{1}$ Jana Dobra, ${ }^{1}$ Vlastimil Kulda, ${ }^{1}$ Michaela Kripnerova, \\ Amin Moztarzadeh, ${ }^{1}$ Lukas Bolek, ${ }^{3}$ Jiri Lahoda, ${ }^{4}$ and Daniel Hrusak ${ }^{5}$ \\ ${ }^{1}$ Department of Medical Chemistry and Biochemistry, Faculty of Medicine in Pilsen, Charles University in Prague, \\ Karlovarska 48, 30166 Pilsen, Czech Republic \\ ${ }^{2}$ Department of Biology, Faculty of Medicine in Pilsen, Charles University in Prague, Alej Svobody 76, 32300 Plzen, Czech Republic \\ ${ }^{3}$ Biomedical Center, Faculty of Medicine in Pilsen, Charles University in Prague, Alej Svobody 76, 32300 Pilsen, Czech Republic \\ ${ }^{4}$ Department of Applied Electronics and Telecommunications, Faculty of Electrical Engineering, University of West Bohemia, \\ Univerzitni 26, 30614 Pilsen, Czech Republic \\ ${ }^{5}$ Department of Stomatology, Faculty of Medicine in Pilsen, University Hospital and Charles University, \\ Alej Svobody 80, 30100 Pilsen, Czech Republic
}

Correspondence should be addressed to Vaclav Babuska; vaclav.babuska@lfp.cuni.cz

Received 24 September 2015; Revised 23 November 2015; Accepted 26 November 2015

Academic Editor: Daniel S. Oh

Copyright (C) 2015 Vaclav Babuska et al. This is an open access article distributed under the Creative Commons Attribution License, which permits unrestricted use, distribution, and reproduction in any medium, provided the original work is properly cited.

The in vitro response of human fibroblast cell line HFL1 and human osteoblast cell line hFOB 1.19 on nanostructured titanium with different grain sizes has been compared in the present study. Used samples of titanium produced by equal channel angular (ECA) pressing have grain sizes of $160 \mathrm{~nm}, 280 \mathrm{~nm}$, and $2400 \mathrm{~nm}$ with cross- and longitudinal sections. Similar cellular behaviour was observed on all studied biomaterials. There were significant differences related to the initial phase of attachment, but not in proliferation. Furthermore, the results indicate that osteoblasts grow best on material with grain size of $160 \mathrm{~nm}$ with a longitudinal section in comparison with other examined materials. Therefore, this material could be recommended for further evaluation with respect to osseointegration in vivo.

\section{Introduction}

Titanium is commonly used for dental as well as orthopaedic implants due to its properties such as biocompatibility, nontoxicity, and corrosion resistance. [1-10]. However, commercially pure titanium (cpTi) has excellent biocompatibility but relatively poor strength, and titanium alloys have superior strength but they contain potentially toxic or allergic ingredients [11, 12]. Long-term stability of the titanium implants is related to their wear resistant properties. Loosening or failure of the implant can be caused by inflammation and bone resorption induced by the wear debris in the form of titanium particles derived from the implants entering into the surrounding tissues [13]. Therefore, it is essential to improve the biocompatibility and wear resistance of a titanium implant for its successful long-term survival [14].
An important direction intensively developed in recent years is the investigation of mechanical properties of nanostructured materials. The formation of nanostructures in metals leads to higher strength. There is great interest in the processing of bulk, fully dense nanostructured metals and alloys. The fabrication of such materials based on severe plastic deformation (SPD) methods seems very interesting and useful. The first developments and investigation of nanostructured materials processed using SPD methods were carried out by Valiev and colleagues more than two decades ago [15-17]. The method for large plastic deformations and formation of nanostructures in our study was equal channel angular (ECA) pressing. The ECA pressing method was carried out by deformation of massive billets via pure shear. Its goal is to introduce an intense plastic strain into materials without changing the cross-section area of billets. Due to 
that, their repeat deformation is possible. The method was further developed and applied as an SPD method for processing structures with submicron and nanometric grain sizes. Nanostructured titanium produced by SPD processing binds together the advantages of aforementioned materials, that is, excellent biocompatibility and extraordinary mechanical properties $[11,18]$. There are not many companies producing bulk nanotitanium and the cost of this material is very high, approximately 10 times higher than conventional titanium [19].

It is known that nanostructuring of material changes its biological properties compared with material of the same chemical composition, but the mechanism of this phenomenon has not yet been clarified [20]. The first evidence of such an effect was provided by Webster et al. in 1999, who found that osteoblast adhesion and bone formation significantly increased on nanostructured titanium surface compared with conventional titanium [21]. Since that time many in vitro as well as in vivo studies have investigated the impact of the nanostructured surface on the behaviour of cells and provide evidence that key biological processes, such as proliferation, gene expression, and initial protein adsorption that control such events, can be easily manipulated by modifying the nanotopography of implants [22-24]. It has also been proven that cells sense and react to nanotopography, by exhibiting changes in cell morphology, orientation, and cytoskeletal organisation [25-27].

An important issue is to improve osseointegration of an implant to its surrounding natural bone tissue [14, 28]. The long-term success of a dental implant depends not only on the integrity of osseointegration but also on the contact with surrounding soft tissue [29-31]. It is well known that cellular behaviour, such as adhesion, morphologic change, migration, functional alteration, and proliferation, is determined by surface properties such as composition, surface energy, topography, and roughness [32-35]. Nanotopography of an implant improves and accelerates osseointegration [19, 36]. Cell lines have been widely investigated as model systems to explore the influence of nanoscale surface topography on cellular response [37].

The aim of the present study was to compare nanostructured titanium with different grain size with respect to biocompatibility using human fibroblast cell line HFLl as well as human osteoblast cell line hFOB 1.19.

\section{Material and Methods}

2.1. Materials. All the samples were obtained from commercially pure titanium (cpTi) by the ECA pressing method from cpTi grade 2 . They have a cylinder shape with a diameter of 4.98-5.05 mm and height of 2.93-3.01 mm (Figure 1(a)). Used samples of titanium have grain sizes of $160 \mathrm{~nm}, 280 \mathrm{~nm}$, and $2400 \mathrm{~nm}$. For each grain size there were two types of sample: cross-section (-) and longitudinal section (+) (Figures 1(c) and $1(\mathrm{~d})$, resp.).

Each implant was cleaned and sterilised before usage. The procedure contains incubation in a trypsin solution $(0.25 \%$ (w/v) Trypsin-0,53 nM EDTA solution, PAA Laboratories $\mathrm{GmbH}$, Austria) $\left(30\right.$ minutes, $\left.37^{\circ} \mathrm{C}\right)$, followed by incubation in an ultrasonic bath $\left(20\right.$ minutes, $\left.25^{\circ} \mathrm{C}\right)$ incubation in acetone $\left(20\right.$ minutes, $\left.25^{\circ} \mathrm{C}\right)$, and at the end rinse in $70 \%$ ethanol and deionised water. Finally the implants were sterilised by autoclaving.

2.2. Characterization of Surfaces. All the sample types with different grain sizes and sections were analysed by scanning electron microscopy (SEM; JSM 6380, JEOL, Japan). Secondary electron channel was used for the observation.

The surface roughness of each sample was measured three times using a mechanical contact profilometer Surtronic 25 (Taylor Hobson, UK). Surface roughness of samples was quantified by arithmetical mean roughness $R a$ (defined as arithmetic average of the absolute values of the profile height deviations from the mean line) and ten-point mean roughness $R z$ (defined as the sum of the average value of absolute values of the heights of five highest profile peaks and the depths of five deepest profile valleys measured in the vertical magnification direction from the mean line). The surface roughness was measured at a traverse speed of $1 \mathrm{~mm} / \mathrm{s}$ with a diamond-tipped stylus with $5 \mu \mathrm{m}$ radius. The average of the three measurements was recorded as the mean surface roughness for each specimen.

2.3. Cell Cultures. Both used cell lines were obtained from ATCC (American type culture collection, Rockville, MD, USA) and cultured in accordance with ATCC recommendations. Culture media were refreshed as needed.

Human fetal lung fibroblasts (HFL1, ATCC, and CCL153) were cultivated in F12K Medium (PAA Laboratories $\mathrm{GmbH}$, Austria) supplemented with $10 \%(\mathrm{v} / \mathrm{v})$ fetal bovine serum (FBS, PAA Laboratories GmbH, Austria), $100 \mathrm{U} / \mathrm{mL}$ penicillin and $100 \mathrm{mg} / \mathrm{mL}$ streptomycin (PAA Laboratories $\mathrm{GmbH}$, Austria), and $2.5 \mathrm{mM}$ L-glutamine (Gibco, Life Technologies, Paisley, UK) at $37^{\circ} \mathrm{C}$ under $5 \% \mathrm{CO}_{2}$ in a humidified incubator.

A human fetal osteoblast cell line, hFOB 1.19 (ATCC, CRL11372), established by Harris et al. [38], was grown in a 1:1 mixture of Ham's F12 Medium and Dulbecco's Modified Eagle's Medium with $2.5 \mathrm{mM} \mathrm{L}$-glutamine (without phenol red) (Gibco, Life Technologies, Paisley, UK) supplemented with $10 \%(\mathrm{v} / \mathrm{v})$ FBS and $0.3 \mathrm{mg} / \mathrm{mL}$ geneticin (G418, Serva Electrophoresis $\mathrm{GmbH}$, Heidelberg, Deutschland). Cells were maintained at $34^{\circ} \mathrm{C}$ under $5 \% \mathrm{CO}_{2}$ in a humidified incubator.

2.4. Cell Viability and Proliferation. Cell proliferation after 48 hours from plating was assessed by MTT viability and proliferation assay (ScienCellTM Research Laboratories, Carlsbad, CA, USA) according to the manufacturer's instruction. This assay is based on the conversion of pale yellow tetrazolium MTT [3-(4,5-dimethylthiazol-2-yl)-2,5-diphenyltetrazolium bromide] to purple formazan crystals, which can be solubilised and then spectrophotometrically quantified.

The samples of implants were placed into a 96-well plate (TPP, St. Louis, MO, USA). Cells harvested with trypsin solution from Petri dishes were resuspended in culture medium and seeded at a density of approximately 500,000 cells $/ \mathrm{mL}$ onto the top of the discs of nanostructured titanium 


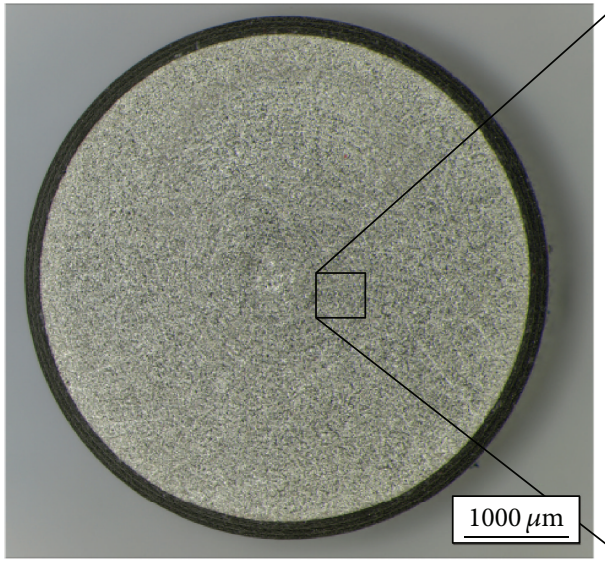

(a)

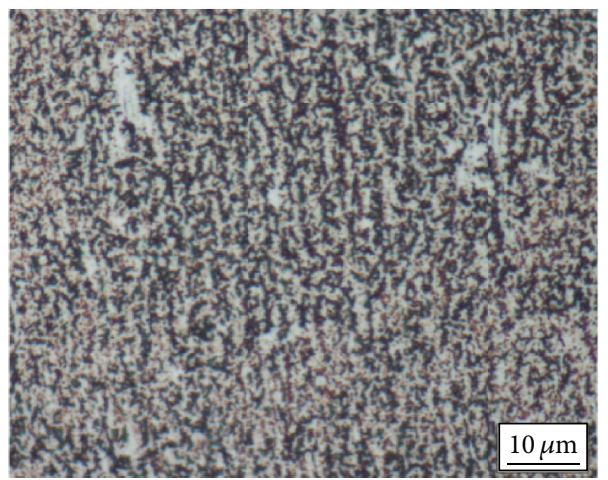

(c)

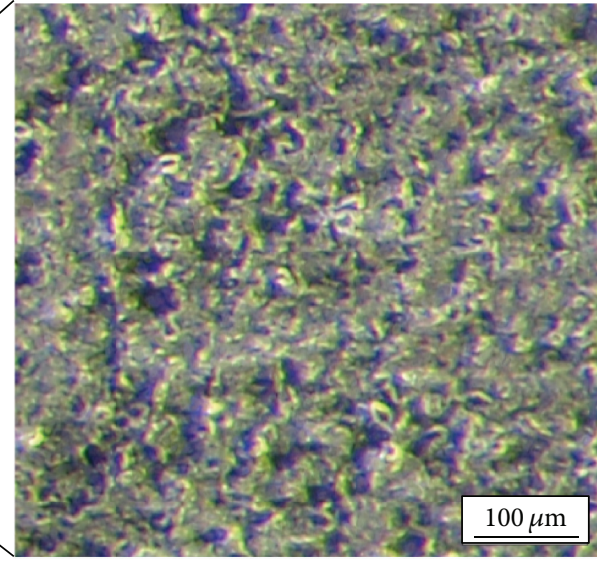

(b)

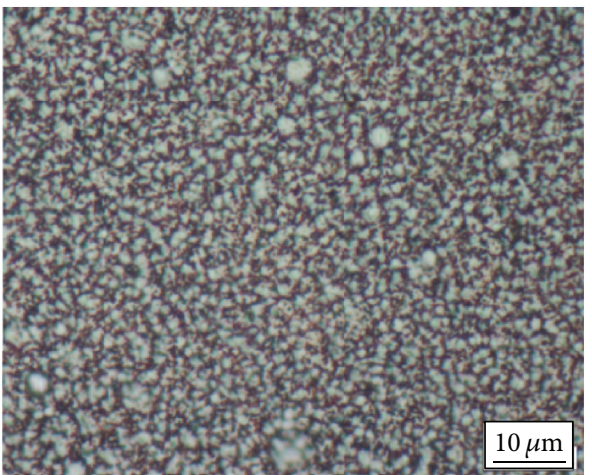

(d)

FIGURE 1: Photographs illustrating nanostructured titanium samples. (a) Macroscopic image; (b) details of the surface; (c) SEM images of longitudinal section; (d) SEM images of transversal cross-section.

in $20 \mu \mathrm{L}$ volume. As positive control, cells grown directly on the 96-well tissue culture plate were used.

After 48-hour incubation, cells were washed with phosphate-buffered saline (PBS) and incubated with $10 \mu \mathrm{L}$ MTT $(25 \mathrm{mg} / \mathrm{mL})$ solution at $37^{\circ} \mathrm{C}$. After 4 hours, $100 \mu \mathrm{L}$ of MTT solubilisation buffer (equal to the volume of original culture medium) was added to each well and the insoluble formazan formed was dissolved by pipetting up and down. The absorbance was measured at $570 \mathrm{~nm}$ (spectrophotometer Nano Drop 1000, Thermo Fisher Scientific, Waltham, MA, USA), subtracting the background absorbance determined at $690 \mathrm{~nm}$.

\subsection{Fluorescent Microscopy}

2.5.1. Cells Staining. Cultured cells were stained with CellTracker Green 5-chloromethylfluorescein diacetate (CMFDA) (Molecular Probes, Inc., Eugene, Oregon, USA) according to the manufacturer's instruction. Briefly, cells were properly washed with PBS and incubated with $4 \mu \mathrm{M}$ CMFDA working solution for $30 \mathrm{~min}$ at $37^{\circ} \mathrm{C}$. Then, the dye working solution was replaced with fresh, prewarmed medium and the cells were incubated for another 30 minutes at $37^{\circ} \mathrm{C}$. Stained cells were analysed using an Olympus IX 70 fluorescent microscope equipped with Cell R system at 40x, 100x, and 400x magnification.

The initial cell attachment and the spreading of the cells on the substrate with different grain size were examined after $6 \mathrm{~h}$ and $24 \mathrm{~h}$, respectively. The area occupied by the cells was assessed by analysis of gained images by the programme ImageJ (W. S. Rasband, U. S. National Institutes of Health, Bethesda, Maryland, USA).

2.5.2. Immunocytochemistry. The samples of implants were placed into a 24-well plate. Five hundred cells were seeded onto the top of the discs of nanostructured titanium cells and incubated for 2 or 48 hours. Fixation was performed by $3 \%$ formaldehyde in PBS for $15 \mathrm{~min}$ at $37^{\circ} \mathrm{C}$ followed by three rinses with PBS. Permeabilisation was carried out by incubation with $0.1 \%$ triton X-100 solution in PBS for $10 \mathrm{~min}$ at room temperature. Blocking with $2 \%$ normal goat serum (Milipore, Billerica, MA, USA) followed for $1 \mathrm{~h}$ at $4^{\circ} \mathrm{C}$. Each sample was double stained. Indirect immunofluorescence staining was done with a mouse monoclonal antivinculin antibody HVIN-1 diluted in PBS $(1: 100)$ and goat $\alpha$-mouse Atto488 conjugated secondary antibody. For actin staining, Phaloidin-Tetramethylrhodamine B isothiocyanate (TRITC) was added into the solution of secondary antibody in 


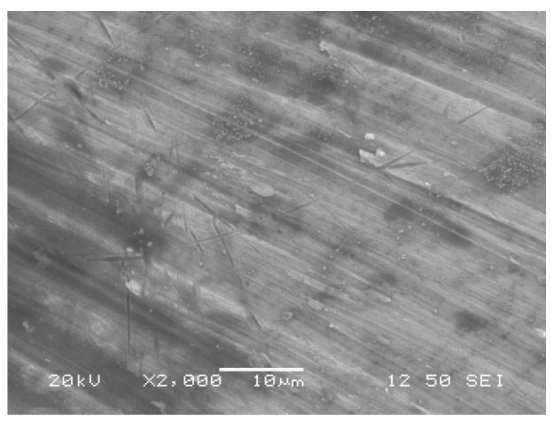

(a)

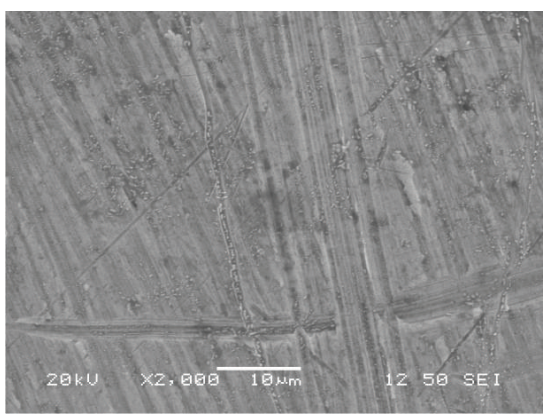

(d)

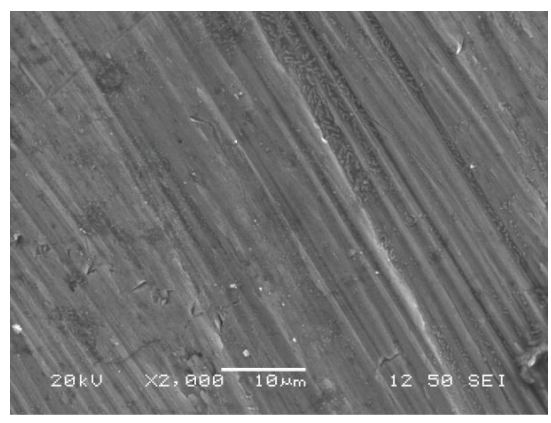

(b)

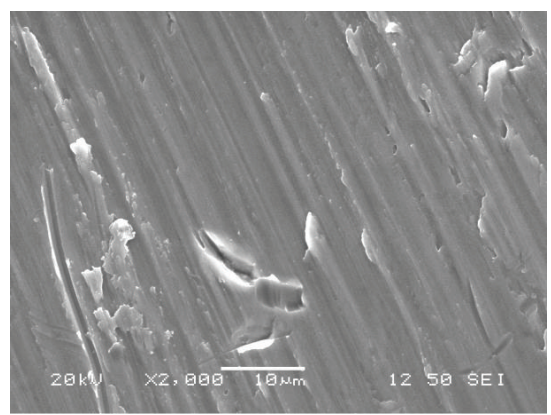

(e)

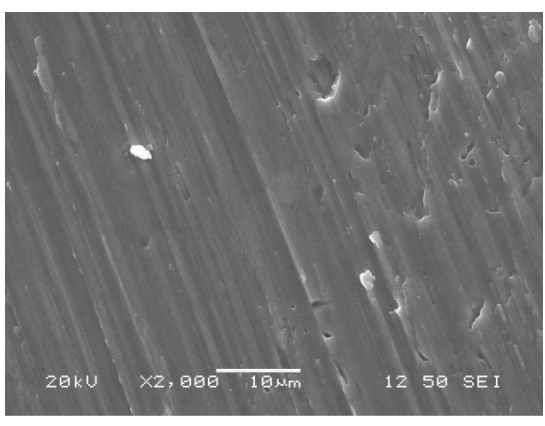

(c)

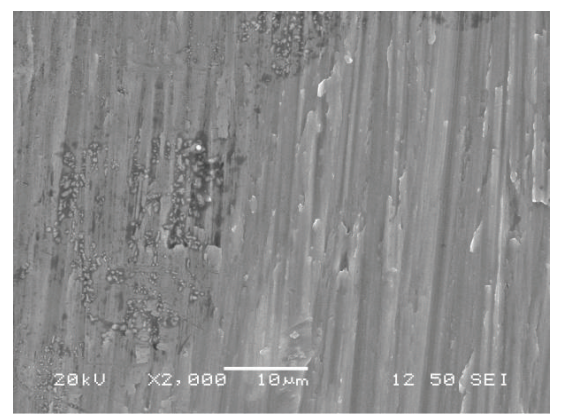

(f)

FIGURE 2: SEM photographs of the sample surfaces with different grain sizes and sections. (a, b, c) SEM images of longitudinal section with grain sizes of 160, 280, and $2400 \mathrm{~nm}$, respectively; (d, e, f) SEM images of transversal cross-section with grain sizes 160, 280, and 2400 nm, respectively.

PBS (0.75 Atto488: 1.5 TRITC: 100 PBS) (Sigma-Aldrich, St. Louis, MO, USA). Incubation with primary antibody was overnight. The second incubation was 2 hours at room temperature in the dark. Samples were analysed using an Olympus IX 70 fluorescent microscope equipped with a Cell $\mathrm{R}$ system at 40x, 100x, and 400x magnification.

2.6. Statistical Analysis. Microscopic analysis was carried out two times at a minimum, using two samples per group. In case of MTT assay, two independent experiments with quadruplicate measurements were performed. Cell viability was compared by analysis of variance (ANOVA). If ANOVA indicated a significant difference $(P<0.05)$ statistical comparisons were computed by two-tailed unpaired $t$-test with the value of significance $P<0.05$. Statistical analysis was performed using the SigmaPlot 12.5 software (Systat Software Inc., San Jose, California, USA).

\section{Results}

3.1. Sample Characterization. Sample characterization was performed by SEM. Figure 2 shows SEM images of the titanium sample surfaces.

The surface roughness quantified by arithmetical mean roughness $R a$ and ten-point mean roughness $R z$ of each sample is shown in Figure 3. Values of $R a$ were between 0.3 and $0.6 \mu \mathrm{m}$ and $R z$ between 1.5 and $3.0 \mu \mathrm{m}$. We did not

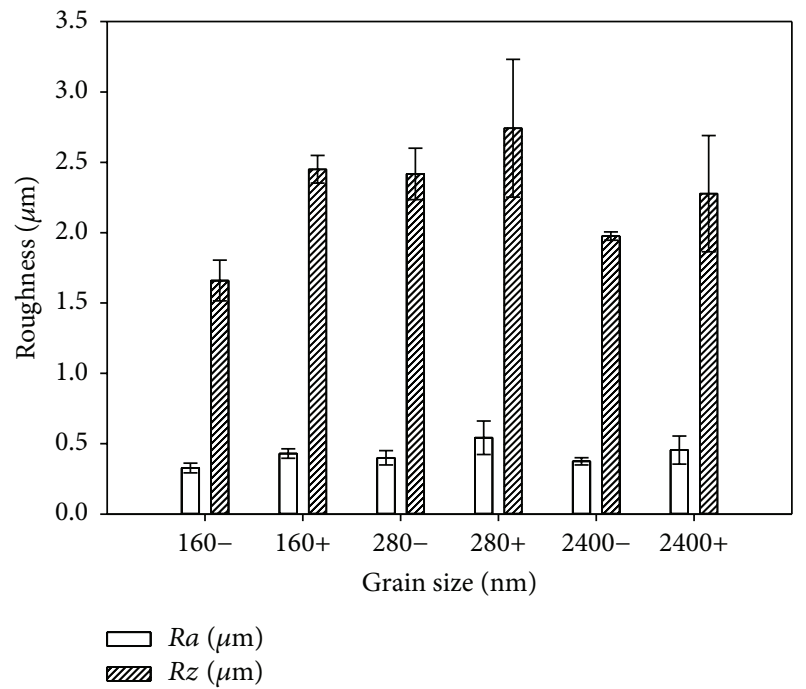

FIgURE 3: The surface roughness expressed by arithmetical mean roughness $R a$ and ten-point mean roughness $R z$. The standard errors were calculated from three independent measurements. Error bars indicate means \pm standard deviations.

find any significant differences in surface roughness (for both parameters $R a$ and $R z)$ among studied materials $(P=0.1097$ and $P=0.0623$, resp.). 


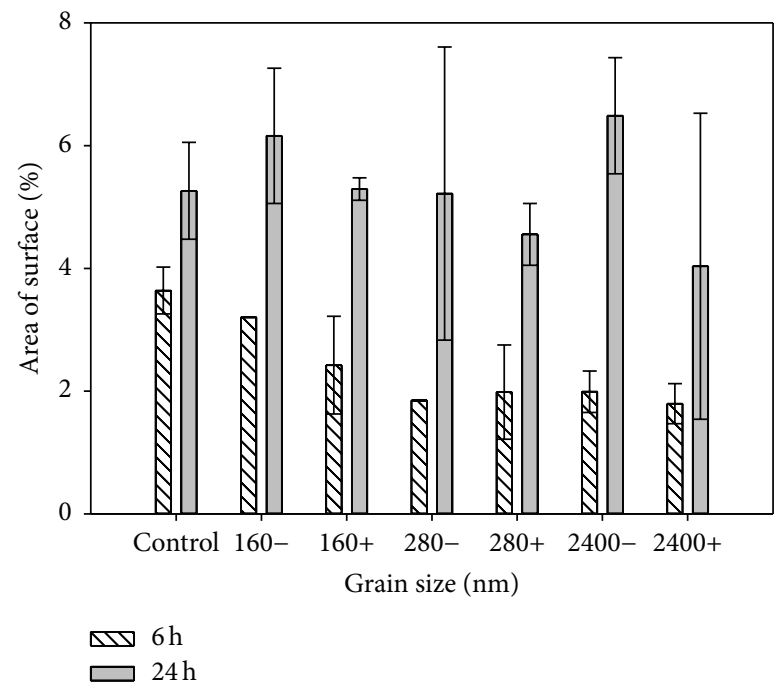

FIGURE 4: The area of surface (percentage) of six studied titanium materials with different grain sizes and sections occupied by human fibroblasts HFL1 at $6 \mathrm{~h}$ and $24 \mathrm{~h}$ after plating. Results from two distinct experiments on the basis of duplicate determination were combined. Error bars indicate means \pm standard deviations.

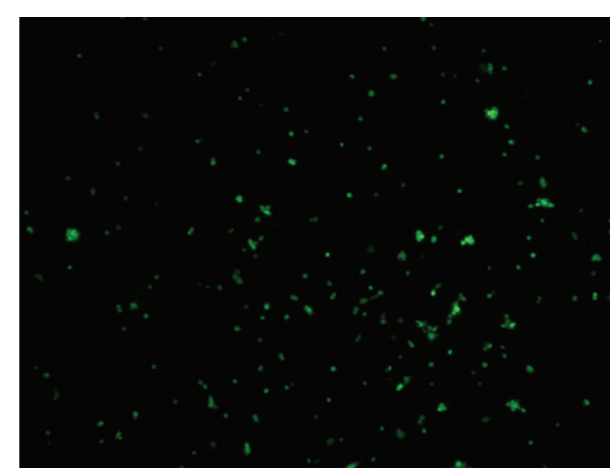

(a)

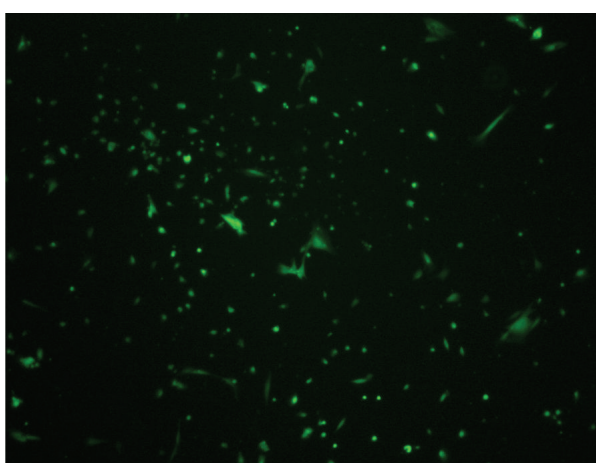

(c)

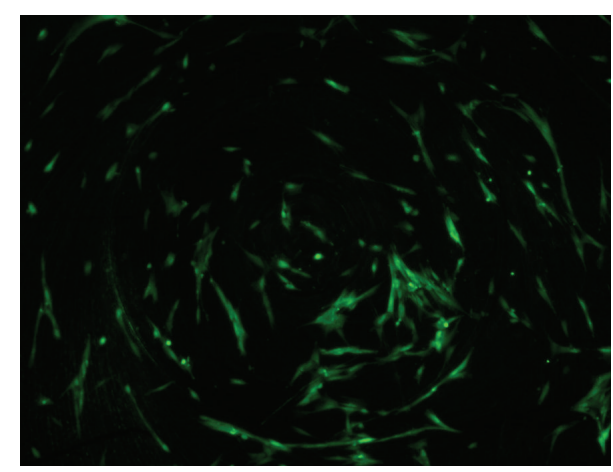

(b)

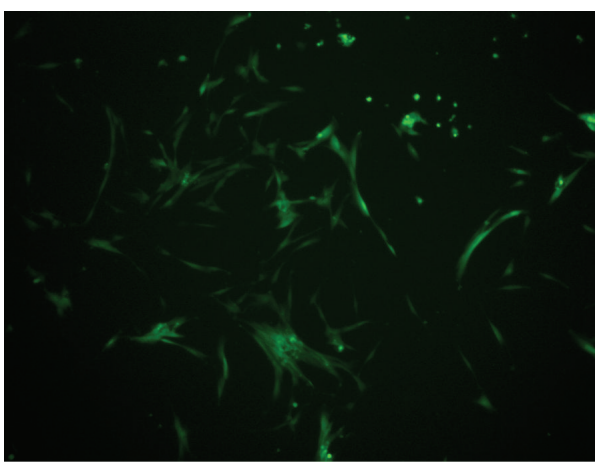

(d)

FIGURE 5: Fluorescence photographs of human fibroblasts HFL1 on tested titanium material (a, b) as well as control (c, d) at $6 \mathrm{~h}(\mathrm{a}, \mathrm{c})$ and $24 \mathrm{~h}$ (b, d) after plating, 40x magnification.

\subsection{Cell Viability and Proliferation}

3.2.1. Cell Adherence and Spreading. The initial cell attachment within the first 6 hours was significantly slower on titanium materials with grain size $2400(-$ and +$) \mathrm{nm}$ and $280(-$ and +$) \mathrm{nm}$, when compared with control (tissue culture plate) $(P=0.0043)$ (Figures $4,5(\mathrm{a})$, and 5(c)). The cells adhered to the surface with $160(-$ and +$) \mathrm{nm}$ grains as well as to control plate. The area occupied by fibroblasts on all studied materials reached very similar values as the control at 24 hours of cultivation (Figures 4, 5(b), and 5(d)). We also analysed differences between particular materials. 
The occupied area after 6 hours was significantly higher on material 160- in contrast to 280- and both types of 2400 (and +$)(P<0.0001 ; P=0.0170 ; P=0.0259$; resp. $)$.

Microscopic observation revealed that after $6 \mathrm{~h}$, fibroblasts presented a mainly rounded morphology (Figures 5(a) and 5(c)). After $24 \mathrm{~h}$ the cells elongated and presented a mainly spindle-like structure. On the tissue culture plastic, we did not see any specific orientation (Figure 5(d)). However, on material samples the cells were aligned along concentric grooves (Figures 1(b) and 5(b)).

3.2.2. MTT Assay. The viability of two cell lines (hFOB 1.19, HFL1) was estimated by MTT assay (Figure 6). The viability of fibroblasts growing on materials 160-, 280+, and 2400+ was significantly lower than on control plates $(P=0.026)$. The osteoblast viability was lower, when growing on all types of studied titanium materials with the exception of $160+$ material in comparison with the control $(P<0.0001)$.

The medians of viability of the cells (\% of positive control) are shown in Table 1 . We found higher viability of osteoblasts comparing materials $280-$ with $160+$ and $2400+$ with $160+$ ( $P=0.0162, P=0.0372$; resp.). The comparison of other pairs of materials did not exhibit any significant differences. On the other hand, material 160+ was a significantly better substrate for culturing osteoblasts than all other studied materials $(P=0.0072)$.

3.3. Immunocytochemistry. In order to compare morphology of the cytoskeleton, fibroblastic cells grown on the six different titanium materials underwent actin labelling with TRITC conjugated phalloidin and vinculin labelling with goat $\alpha$-mouse Atto488 conjugated secondary antibody for mouse monoclonal anti-human vinculin antibody HVIN-1 (Figure 7).

Two hours after seeding, cytoskeleton analysis showed that cells presented a round shape and were not yet spread properly on the surfaces. On all tested materials, at this point in time, focal contacts could be seen as positive spots localised at the cellular edge.

After 48 h,the cytoskeleton analysis mainly showed cells with an elongated bipolar morphology. On all tested surfaces, vinculin-positive focal contacts were present homogenously on the whole cell surface, with a slightly higher density at the cell periphery, at the ends of F-actin filaments. These data denote that the adhesion phase occurred on all tested materials.

\section{Discussion}

In our work we examined how grain size of nanostructured titanium material influences the behaviour of fibroblastic as well as osteoblastic cells grown on its surface.

The grain size was shown to be an important factor that influenced not only the strength of material but also its interactions with cells. Kim et al. proved that the ultrafine grain titanium prepared by the ECAP method had better biocompatibility concerning wettability, cell adhesion, and proliferation of mouse fibroblasts [39]. Our results did not
TABLE 1: Medians of viability of two cell lines (hFOB 1.19, HFL1) estimated by MTT assay expressed as $\%$ of positive control.

\begin{tabular}{lcccccc}
\hline \multirow{2}{*}{ Material } & \multicolumn{3}{c}{ Cross-section } & \multicolumn{3}{c}{ Longitudinal section } \\
& $160-$ & $280-$ & $2400-$ & $160+$ & $280+$ & $2400+$ \\
\hline hFOB 1.19 & 72.2 & 62.2 & 68.5 & 91.5 & 62.3 & 62.3 \\
HFL1 & 68.1 & 71.4 & 77.5 & 77.8 & 71.5 & 73.4 \\
\hline
\end{tabular}

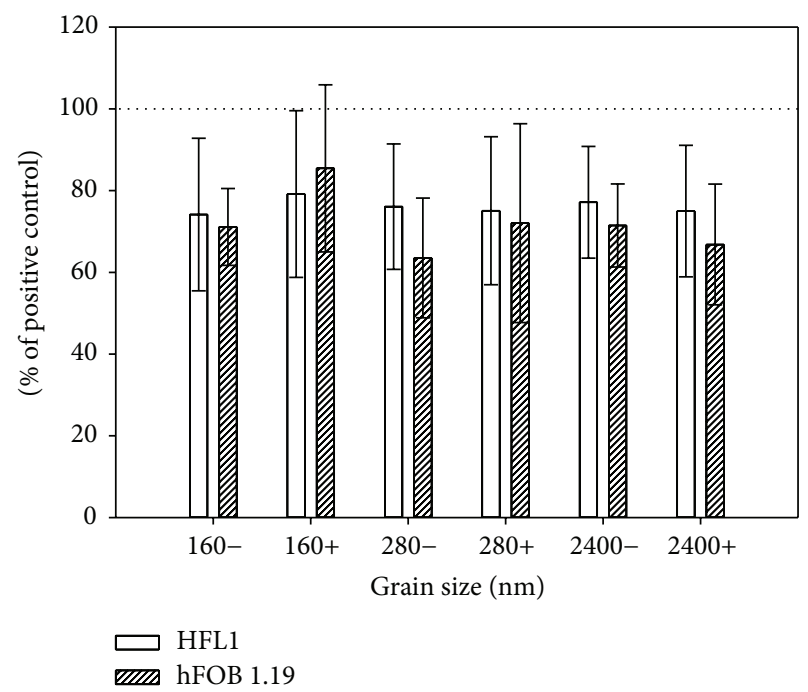

FIGURE 6: Comparison of the viability assessed by MTT assay of human fibroblasts HFL1 and human fetal osteoblast cell line, hFOB 1.19 grown on six studied titanium materials with different grain sizes. The standard errors were calculated from a combination of two independent experiments with quadruplicate measurements. Data expressed as \% of positive control. Error bars indicate means \pm standard deviations.

clearly prove that grain size has a distinct impact on viability or proliferation of used fibroblast model (HFL1). The only differences we saw were related to the initial phase of attachment, but until 24 hours after seeding, differences almost disappear. We saw faster cell attachment on material with the smallest grain size in examination.

The metabolic activity, assessed by MTT test, of the cells grown on 160-, 280+, and 2400+ titanium was significantly decreased against control. However, the tested materials did not differ among each other, which indicated that all tested materials were cytocompatible. This is in line with the numerous studies demonstrating the biocompatible character of titanium as a substrate for cell culturing [40-43].

The usage of a second cell model (hFOB 1.19) revealed that one of the tested materials seems to be as good as control with respect to metabolic activity of the osteoblasts cultured on its surface. It was the material with the smallest grain size that seemed to be consistent with the studies that detected that the smaller the grain size, the better the viability [44-46]. Other studied materials were significantly worse than control and $160+$. Interestingly, this result was reached only for one of two materials with one certain grain size. This observation indicated that two different sections differ in the viability of cells grown on its surface, which is in agreement with 


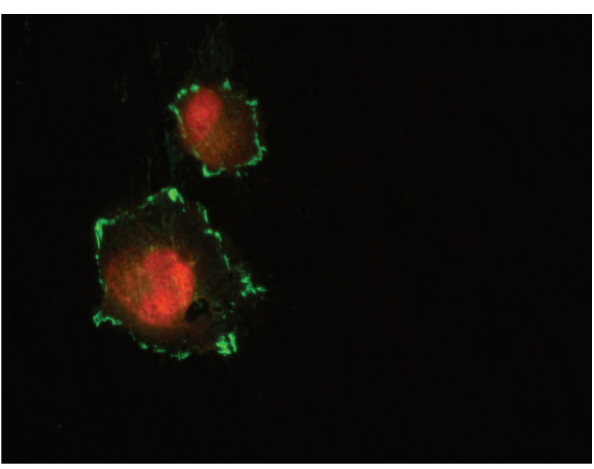

(a)

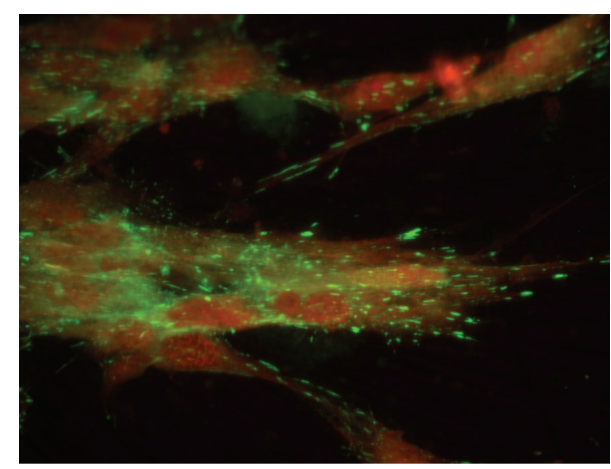

(b)

FIGURE 7: Visualisation of focal adhesion and cytoskeleton of human fibroblasts HFL1 on tested titanium material after $2 \mathrm{~h}$ (a) and $48 \mathrm{~h}$ (b) of seeding. Actin filament (red), vinculin (green), 400x magnification.

the study of Hoseini et al., who conclude that crystallographic texture, rather than grain size, plays a principal role in the surface biocompatibility [47].

It is well established that the proteins of extracellular matrix, membrane receptors, and cytoskeletal proteins are responsible for cell-substrate interactions. That is why we decided to analyse two important cytoskeletal proteins actin and vinculin by immunocytochemical staining. Actin is a critical player in many cellular functions, such as cell motility and the maintenance of cell shape and polarity [48]. Vinculin is a cytoplasmic actin-binding protein enriched in focal adhesions and adherens junctions required for strong cell adhesion [49]. As early as $2 \mathrm{~h}$ after seeding, the cells adhered and began to spread (Figure 7(a)). The cells displayed wellspreading morphology with many vinculin spots after $24 \mathrm{~h}$ (Figure $7(\mathrm{~b})$ ). This observation proved that the adhesion phase occurred on all tested materials.

We also intend to examine differences between two used cell models. Fibroblasts represent soft tissue and osteoblast hard tissue, and the dental implant needs to be in contact with both. We did not record significant differences in viability among tested materials plating with fibroblast cells. When we used osteoblasts as a cell model, we recorded that material with a grain size $160 \mathrm{~nm}$ with longitudinal section seemed to be as good as a conventional culture plate with respect to cell viability and proliferation. Therefore, this material could be recommended for a detailed study of cell behaviour in vitro as well as in vivo.

\section{Conclusions}

The aim of this study was to evaluate if any of the six studied materials is better than others with respect to biocompatibility and cell proliferation. Similar cellular behaviour was observed on all studied biomaterials. There were differences related to the initial phase of attachment, but not in proliferation. Furthermore, the results reported in this paper indicate that osteoblasts grow on material with a grain size of $160 \mathrm{~nm}$ with longitudinal section as well as on a conventional culture plate, whereas, for other studied materials, we observed decreased viability. This material could be recommended for further evaluation with respect to osseointegration in vivo.

\section{Conflict of Interests}

The authors declare that there is no conflict of interests regarding the publication of this paper.

\section{Acknowledgment}

This study was supported by the National Sustainability Program I (NPU I) Nr. LO1503 provided by the Ministry of Education Youth and Sports of the Czech Republic.

\section{References}

[1] N. G. Durmus and T. J. Webster, "Nanostructured titanium: the ideal material for improving orthopedic implant efficacy?" Nanomedicine, vol. 7, no. 6, pp. 791-793, 2012.

[2] N. K. Tolochko, V. V. Savich, T. Laoui et al., "Dental root implants produced by the combined selective laser sintering/melting of titanium powders," Proceedings of the Institution of Mechanical Engineers, Part L: Journal of Materials: Design and Applications, vol. 216, no. 4, pp. 267-270, 2002.

[3] T. Hayashi, K. Maekawa, M. Tamura, and K. Hanyu, "Selective laser sintering method using titanium powder sheet toward fabrication of porous bone substitutes," JSME International Journal Series A Solid Mechanics and Material Engineering, vol. 48, no. 4, pp. 369-375, 2005.

[4] H. Nakamura, L. Saruwatari, H. Aita, K. Takeuchi, and T. Ogawa, "Molecular and biomechanical characterization of mineralized tissue by dental pulp cells on titanium," Journal of Dental Research, vol. 84, no. 6, pp. 515-520, 2005.

[5] Á. Joób-Fancsaly, T. Divinyi, Á. Fazekas, C. Daroczi, A. Karacs, and G. Petõ, "Pulsed laser-induced micro- and nanosized morphology and composition of titanium dental implants," Smart Materials and Structures, vol. 11, no. 5, pp. 819-824, 2002.

[6] H.-M. Kim, H. Takadama, F. Miyaji, T. Kokubo, S. Nishiguchi, and T. Nakamura, "Formation of bioactive functionally graded structure on Ti-6Al-4V alloy by chemical surface treatment," Journal of Materials Science: Materials in Medicine, vol. 11, no. 9, pp. 555-559, 2000. 
[7] P. Fischer, V. Romano, H. P. Weber, N. P. Karapatis, E. Boillat, and R. Glardon, "Sintering of commercially pure titanium powder with a Nd:YAG laser source," Acta Materialia, vol. 51, no. 6, pp. 1651-1662, 2003.

[8] B. Engel and D. L. Bourell, "Titanium alloy powder preparation for selective laser sintering," Rapid Prototyping Journal, vol. 6, no. 2, pp. 97-106, 2000.

[9] S. Das, M. Wohlert, J. J. Beaman, and D. L. Bourell, "Processing of titanium net shapes by SLS/HIP," Materials \& Design, vol. 20, no. 2-3, pp. 115-121, 1999.

[10] I. V. Shishkovskii, Y. G. Morozov, S. V. Fokeev, and L. T. Volova, "Laser synthesis and comparative testing of a three-dimensional porous matrix of titanium and titanium nickelide as a repository for stem cells," Powder Metallurgy and Metal Ceramics, vol. 50, no. 9-10, pp. 606-618, 2012.

[11] J. Petruzelka, L. Dluhos, D. Hrusak, and J. Sochova, "Nanostructured titan-a new material for dental implants," Česká Stomatologie, vol. 106, no. 3, pp. 72-77, 2006.

[12] J. Vanek, "Klasifikace materialu," in Dentalni Implantologie, A. Simunek, Ed., pp. 29-33, Nucleus HK, Hradec Kralove, Czech Republic, 2nd edition, 2008.

[13] C. A. St Pierre, M. Chan, Y. Iwakura, D. C. Ayers, E. A. KurtJones, and R. W. Finberg, "Periprosthetic osteolysis: characterizing the innate immune response to titanium wear-particles," Journal of Orthopaedic Research, vol. 28, no. 11, pp. 1418-1424, 2010.

[14] M. Lai, K. Cai, Y. Hu, X. Yang, and Q. Liu, "Regulation of the behaviors of mesenchymal stem cells by surface nanostructured titanium," Colloids and Surfaces B: Biointerfaces, vol. 97, pp. 211220, 2012.

[15] R. Z. Valiev, O. A. Kaibyshev, R. I. Kuznetsov, R. S. Musalimov, and N. K. Tsenev, "The low-temperature superplasticity of metallic materials," Doklady Akademii Nauk SSSR (Proceedings of the Academy of Sciences of the USSR), vol. 301, no. 4, pp. 864$866,1988$.

[16] R. Z. Valiev, N. A. Krasilnikov, and N. K. Tsenev, "Plastic deformation of alloys with submicron-grained structure," Materials Science and Engineering A, vol. 137, pp. 35-40, 1991.

[17] R. Z. Valiev, R. K. Islamgaliev, and I. V. Alexandrov, "Bulk nanostructured materials from severe plastic deformation," Progress in Materials Science, vol. 45, no. 2, pp. 103-189, 2000.

[18] R. Z. Valiev, I. P. Semenova, V. V. Latysh et al., "Nanostructured titanium for biomedical applications," Advanced Engineering Materials, vol. 10, no. 8, pp. B15-B17, 2008.

[19] D. Kopecka, A. Simunek, and R. Slezak, "Nanomaterials in dentistry-state of the art," Praktické Zubní Lékařství, vol. 57, no. 4, pp. 59-62, 2009.

[20] D. Hrusak, M. Zemko, L. Dluhos, and L. Kraus, "Usage of nanostructured titanium for endosteal implants," in Proceedings of the 1st Conference with International Participation Nanocon, S1B3, Roznov pod Radhostem, Czech Republic, October 2009.

[21] T. J. Webster, R. W. Siegel, and R. Bizios, "Osteoblast adhesion on nanophase ceramics," Biomaterials, vol. 20, no. 13, pp. 12211227, 1999.

[22] N. Tran and T. J. Webster, "Nanotechnology for bone materials," Wiley Interdisciplinary Reviews: Nanomedicine and Nanobiotechnology, vol. 1, no. 3, pp. 336-351, 2009.

[23] G. Balasundaram and T. J. Webster, "A perspective on nanophase materials for orthopedic implant applications," Journal of Materials Chemistry, vol. 16, no. 38, pp. 3737-3745, 2006.
[24] F. Varíola, F. Vetrone, L. Richert et al., "Improving biocompatibility of implantable metals by nanoscale modification of surfaces: an overview of strategies, fabrication methods, and challenges," Small, vol. 5, no. 9, pp. 996-1006, 2009.

[25] M. J. Dalby, N. Gadegaard, R. Tare et al., "The control of human mesenchymal cell differentiation using nanoscale symmetry and disorder," Nature Materials, vol. 6, no. 12, pp. 997-1003, 2007.

[26] S. Oh, K. S. Brammer, Y. S. J. Li et al., "Stem cell fate dictated solely by altered nanotube dimension," Proceedings of the National Academy of Sciences of the United States of America, vol. 106, no. 7, pp. 2130-2135, 2009.

[27] P. Bertoncini, S. Le Chevalier, S. Lavenus, P. Layrolle, and G. Louarn, "Early adhesion of human mesenchymal stem cells on $\mathrm{TiO}_{2}$ surfaces studied by single-cell force spectroscopy measurements," Journal of Molecular Recognition, vol. 25, no. 5, pp. 262-269, 2012.

[28] S. M. Sporer and W. G. Paprosky, "Biologic fixation and bone ingrowth," Orthopedic Clinics of North America, vol. 36, no. 1, pp. 105-111, 2005.

[29] D. Buser, H. P. Weber, K. Donath, J. P. Fiorellini, D. W. Paquette, and R. C. Williams, "Soft tissue reactions to nonsubmerged unloaded titanium implants in beagle dogs," Journal of Periodontology, vol. 63, no. 3, pp. 225-235, 1992.

[30] M. A. Listgarten, N. P. Lang, H. E. Schroeder, and A. Schroeder, "Periodontal tissues and their counterparts around endosseous implants," Clinical Oral Implants Research, vol. 2, no. 1, pp. 1-19, 1991.

[31] E. Eisenbarth, J. Meyle, W. Nachtigall, and J. Breme, "Influence of the surface structure of titanium materials on the adhesion of fibroblasts," Biomaterials, vol. 17, no. 14, pp. 1399-1403, 1996.

[32] F. H. Jones, "Teeth and bones: applications of surface science to dental materials and related biomaterials," Surface Science Reports, vol. 42, no. 3-5, pp. 75-205, 2001.

[33] B. Größner-Schreiber, M. Herzog, J. Hedderich, A. Dück, M. Hannig, and M. Griepentrog, "Focal adhesion contact formation by fibroblasts cultured on surface-modified dental implants: an in vitro study," Clinical Oral Implants Research, vol. 17, no. 6, pp. 736-745, 2006.

[34] W. Baschong and J. T. Lambrecht, "Influence of the implant surface on the early phase of osteogenesis in vitro," Schweizer Monatsschrift für Zahnmedizin, vol. 114, no. 8, pp. 792-799, 2004.

[35] C. Jin, L.-F. Ren, H.-Z. Ding, G.-S. Shi, H.-S. Lin, and F. Zhang, "Enhanced attachment, proliferation, and differentiation of human gingival fibroblasts on titanium surface modified with biomolecules," Journal of Biomedical Materials Research Part B: Applied Biomaterials, vol. 100, no. 8, pp. 2167-2177, 2012.

[36] L. Meirelles, A. Arvidsson, T. Albrektsson, and A. Wennerberg, "Increased bone formation to unstable nano rough titanium implants," Clinical Oral Implants Research, vol. 18, no. 3, pp. 326332, 2007.

[37] M. S. Lord, M. Foss, and F. Besenbacher, "Influence of nanoscale surface topography on protein adsorption and cellular response," Nano Today, vol. 5, no. 1, pp. 66-78, 2010.

[38] S. A. Harris, R. J. Enger, B. L. Riggs, and T. C. Spelsberg, "Development and characterization of a conditionally immortalized human fetal osteoblastic cell line," Journal of Bone and Mineral Research, vol. 10, no. 2, pp. 178-186, 1995.

[39] T. N. Kim, A. Balakrishnan, B. C. Lee et al., "In vitro biocompatibility of equal channel angular processed (ECAP) titanium," Biomedical Materials, vol. 2, no. 3, pp. S117-S120, 2007. 
[40] S. G. Steinemann, “Titanium-the material of choice?" Periodontology 2000, vol. 17, no. 1, pp. 7-21, 1998.

[41] M. Schuier, D. Trentin, M. Textor, and S. G. P. Tosatti, "Biomedical interfaces: titanium surface technology for implants and cell carriers," Nanomedicine, vol. 1, no. 4, pp. 449-463, 2006.

[42] L. Le Guehennec, M.-A. Lopez-Heredia, B. Enkel, P. Weiss, Y. Amouriq, and P. Layrolle, "Osteoblastic cell behaviour on different titanium implant surfaces," Acta Biomaterialia, vol. 4, no. 3, pp. 535-543, 2008.

[43] Y. Estrin, H.-E. Kim, R. Lapovok, H. P. Ng, and J.-H. Jo, "Mechanical strength and biocompatibility of ultrafine-grained commercial purity titanium," BioMed Research International, vol. 2013, Article ID 914764, 6 pages, 2013.

[44] T. N. Kim, A. Balakrishnan, B. C. Lee et al., "In vitro fibroblast response to ultra fine grained titanium produced by a severe plastic deformation process," Journal of Materials Science: Materials in Medicine, vol. 19, no. 2, pp. 553-557, 2008.

[45] Y. Estrin, E. P. Ivanova, A. Michalska, V. K. Truong, R. Lapovok, and R. Boyd, "Accelerated stem cell attachment to ultrafine grained titanium," Acta Biomaterialia, vol. 7, no. 2, pp. 900-906, 2011.

[46] A. Farzin, M. Ahmadian, and M. H. Fathi, "Comparative evaluation of biocompatibility of dense nanostructured and microstructured Hydroxyapatite/Titania composites," Materials Science and Engineering C, vol. 33, no. 4, pp. 2251-2257, 2013.

[47] M. Hoseini, P. Bocher, A. Shahryari, F. Azari, J. A. Szpunar, and H. Vali, "On the importance of crystallographic texture in the biocompatibility of titanium based substrate," Journal of Biomedical Materials Research Part A, vol. 102, no. 10, pp. 36313638, 2014.

[48] R. Dominguez and K. C. Holmes, "Actin structure and function," Annual Review of Biophysics, vol. 40, no. 1, pp. 169-186, 2011.

[49] K. A. DeMali, "Vinculin—a dynamic regulator of cell adhesion," Trends in Biochemical Sciences, vol. 29, no. 11, pp. 565-567, 2004. 

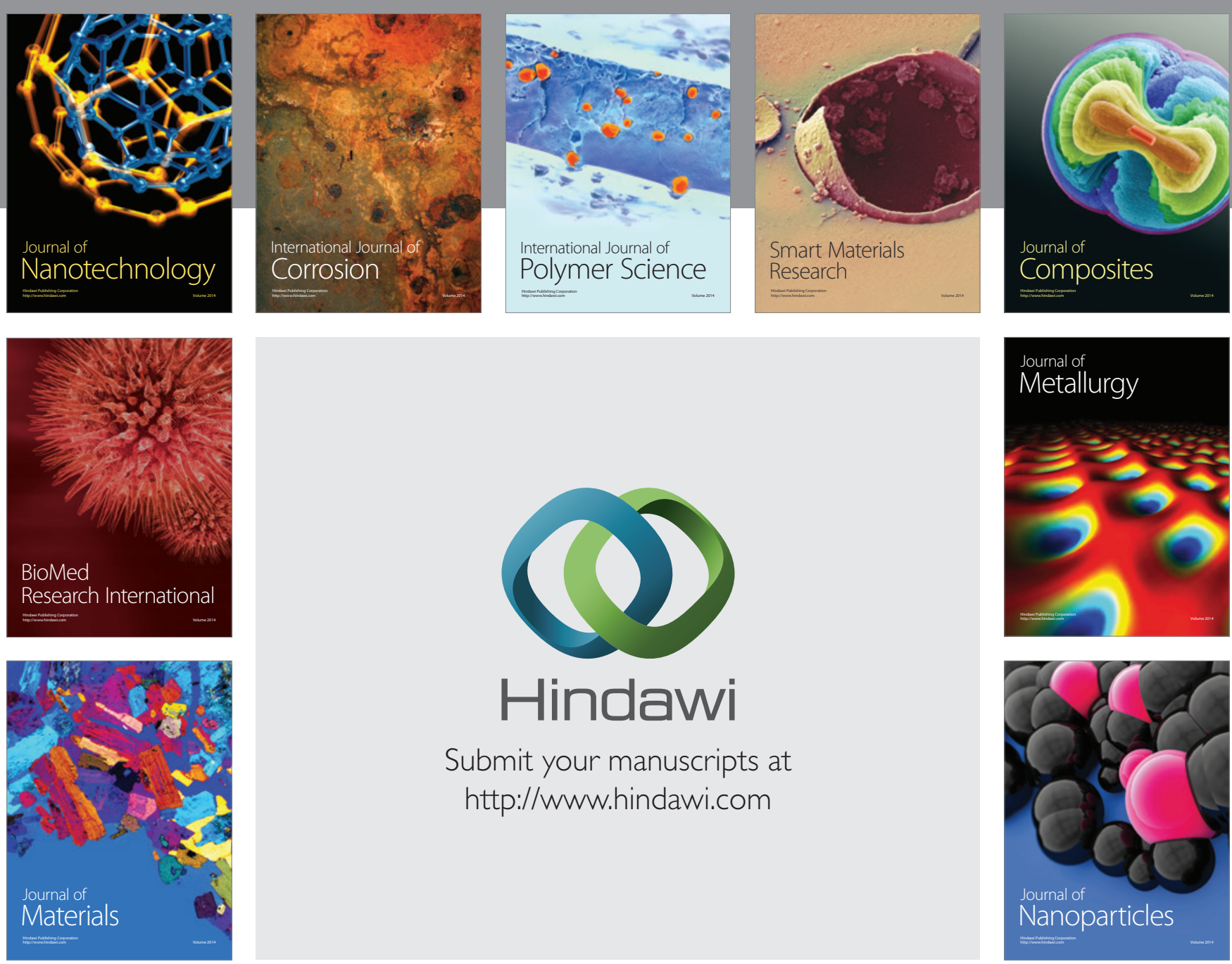

Submit your manuscripts at http://www.hindawi.com
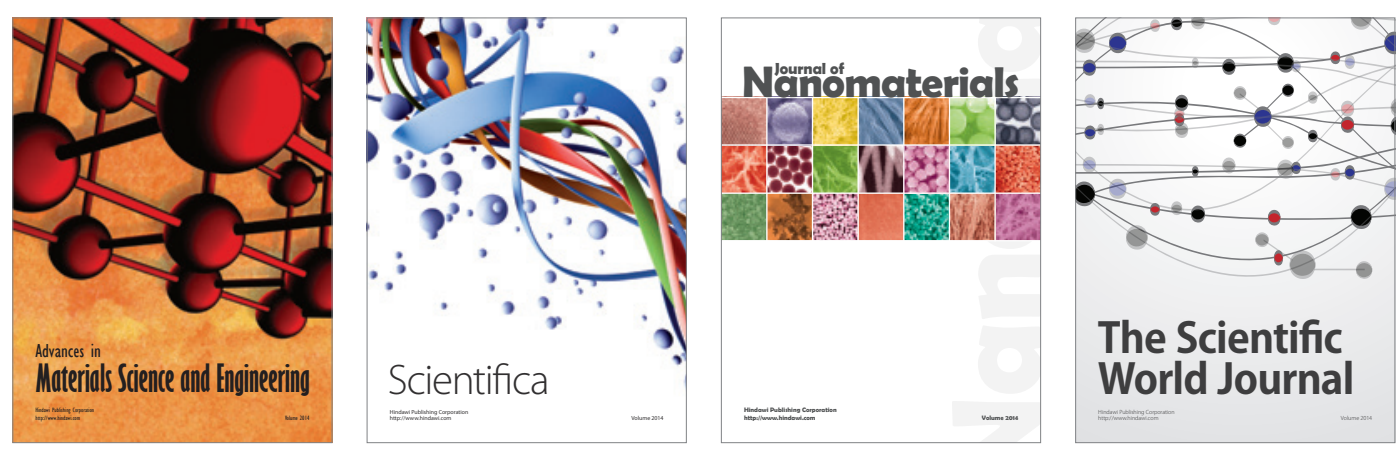

\section{The Scientific World Journal}
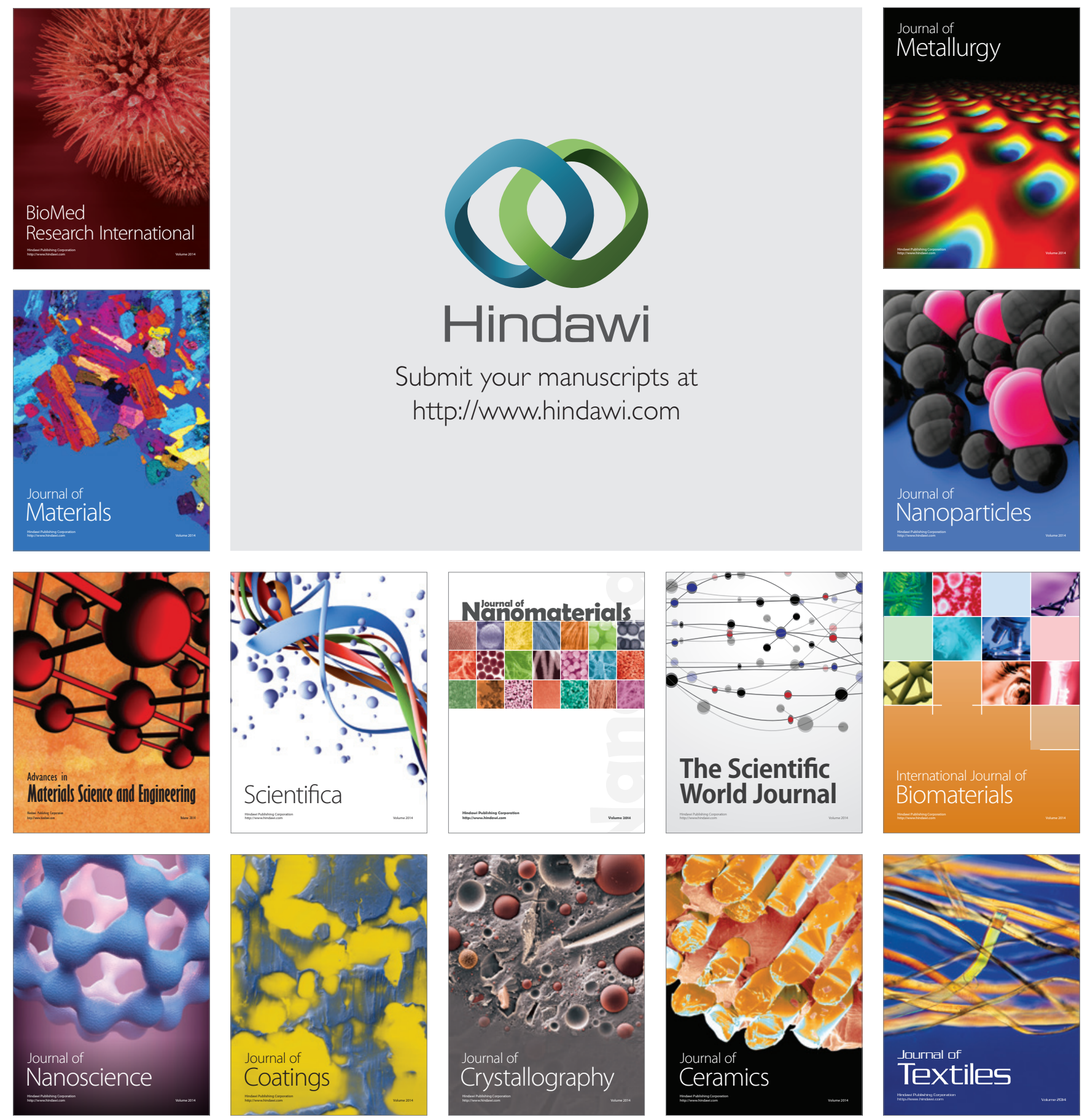